\title{
Bioeconomic Assessment of an Alley Cropping Field Trial in North Carolina, U.S.: Tree Density, Timber Production, and Forage Relationships
}

\author{
Kenneth Dunn ${ }^{1, *}$, Lori Unruh Snyder ${ }^{2}$, James McCarter ${ }^{1}$, Gregory Frey ${ }^{3}{ }^{\circledR}$, Joshua Idassi ${ }^{4}$, David Schnake ${ }^{5}(\mathbb{D})$ \\ and Frederick Cubbage ${ }^{1, *}$ \\ 1 Department of Forestry and Environmental Resources, North Carolina State University, \\ Raleigh, NC 27695-8008, USA; jim.mccarter@rayonier.com \\ 2 Department of Crop and Soil Sciences, North Carolina State University, Raleigh, NC 27695-7578, USA; \\ lori_snyder@ncsu.edu \\ 3 USDA Forest Service, Southern Research Station, Forest Science Assessment Center \\ Research Triangle Park, NC 27709-2254, USA; gregory.e.frey@usda.gov \\ 41890 Research \& Extension, South Carolina State University, Orangeburg, SC 29117, USA; jidassi@gmail.com \\ 5 North Carolina Department of Agriculture and Consumer Services, Raleigh, NC 27699-1001, USA; \\ david.schnake@ncagr.gov \\ * Correspondence: kndunn@ncsu.edu (K.D.); fred_cubbage@ncsu.edu (F.C.); \\ Tel.: +1-843-745-7055 (K.D.); +1-919-515-7789 (F.C.)
}

\section{check for} updates

Citation: Dunn, K.; Unruh Snyder, L.; McCarter, J.; Frey, G.; Idassi, J.; Schnake, D.; Cubbage, F. Bioeconomic Assessment of an Alley Cropping Field Trial in North Carolina, U.S.: Tree Density, Timber Production, and Forage Relationships. Sustainability 2021, 13, 11465. https://doi.org/ $10.3390 /$ su132011465

Academic Editors: Szilvia Bencze and Dóra Drexler

Received: 28 August 2021

Accepted: 6 October 2021

Published: 17 October 2021

Publisher's Note: MDPI stays neutral with regard to jurisdictional claims in published maps and institutional affiliations.

Copyright: (c) 2021 by the authors. Licensee MDPI, Basel, Switzerland. This article is an open access article distributed under the terms and conditions of the Creative Commons Attribution (CC BY) license (https:// creativecommons.org/licenses/by/ $4.0 /)$.

\begin{abstract}
Silvopasture, the combination of trees, forage, and livestock, is a management practice that is gaining interest throughout the southeastern U.S. This research analyzed a hay-based alley cropping field trial that is transitioning into a silvopasture system. We planted four different tree spacings$2.4 \times 2.4 \mathrm{~m}, 2.4 \times 3.0 \mathrm{~m}, 3.0 \times 3.0 \mathrm{~m}$, and $1.8 \times 3.0 \mathrm{~m}(8 \times 8 \mathrm{ft}, 8 \times 10 \mathrm{ft}, 10 \times 10 \mathrm{ft}$, and $6 \times 10 \mathrm{ft})$-of loblolly pine (Pinus taeda L.) and used secondary data for the possible planting of two different grass species-big bluestem (Andropogon gerardii Vitman) and switchgrass (Panicum virgatum L.). Tree inventories, forage samples, biometric modeling, and economic analysis of forage and timber monocultures and mixed systems were analyzed with discounted cash flow and capital budgeting analyses. Tree growth on the pasture site was exceptionally fast, generating high projected returns for timber monocultures, which exceeded returns for monoculture grass crops. Projected timber stand returns had the greatest Net Present Values (NPV) at the 4\% discount rate, ranging between USD 3196 and USD 3552 per ha (USD 1294 and USD 1438 per ac) for a $2.4 \times 3.0 \mathrm{~m}$ or $2.4 \times 2.4 \mathrm{~m}$ tree spacing yield. Representative grass yields were obtained from secondary sources and had lower productivity, with switchgrass having the highest returns at USD 2581 per ha (USD 1045 per ac). Optimal NPVs for mixed silvopasture stands ranged between about USD 1500 per ha and USD 3500 per ha (USD $600 / \mathrm{ac}$ and USD 1400/ac), depending on the tree spacing within bands, the alley spacing, and the degree of competition between trees and grasses.
\end{abstract}

Keywords: alley cropping; silvopasture; agroforestry; trees; forage; economic analysis; capital budgeting; North Carolina

\section{Introduction}

Continual demands for increased food and fiber production and for ecosystem services have prompted innovation in farm and forest systems that can produce multiple goods and services with better environmental outcomes than modern monoculture cropping systems. In particular, multiple output agroforestry systems have been proposed and investigated as promising means to provide more wholistic agroecological systems that can provide a supplement to monocultures, produce substantial amounts of commodity goods and ecosystem services, generate fewer negative externalities, require less herbicides and pesticides, and create more favorable plant and animal health outcomes. 
Of the current broad United Nations Sustainable Development Goals (SDGs) [1], at least three are related closely to agroecological production systems-(12) Responsible Production and Consumption, (13) Climate Action, and (15) Life on Land. Responsible production and consumption clearly infer producing consumer goods that are not only efficient and minimize input factors of production but also minimize short- and long-run adverse environmental impacts. Integrated agroecological systems also can contribute significantly to climate action by minimizing carbon and methane emissions or even offsetting greenhouse gases (GHGs). Furthermore, more diverse agroecological systems can employ natural approaches that can produce and sustain plant, animal, and genetic biodiversity. These three broad SDG themes and others identify dozens of actions that can help build bridges to a more sustainable future. In this research, we examined alley cropping of trees and pasture - the first phase of a tree and livestock system —as one rapidly developing new approach to food and fiber production, which has received increasing attention in developed as well as developing countries.

\subsection{Agro-Silvo-Pastoral Systems}

Agro-silvo-pastoral systems, or silvopasture, are those in which woody perennials are grown with forage crops and livestock [2]. Silvopasture has slowly increased in popularity throughout the southeast U.S. [3,4]. While the production and management system regimes are still under development, landowners using silvopasture seek to diversify their income streams by having multiple products to sell over an extended time frame $[5,6]$.

Past research on silvopasture in the southern United States has highlighted its numerous ecosystem benefits and services compared to monocultures of agriculture crops or forest plantations $[7,8]$. Silvopastures have been shown to sequester and store high levels of above- and below-ground carbon, creating a potential for mitigation of climate change [9]. Silvopasture has higher levels of biodiversity than typical monoculture systems [10].

Furthermore, silvopasture can provide a competitive financial alternative for farmers and landowners. Research conducted over the past several decades suggests that silvopasture can produce financial returns equal to or better than conventional timberland returns. Grass and forage usually are expected to have greater financial returns than timber or silvopasture, but mixed grass and tree systems may have higher net returns than grasses under specific scenarios $[2,5,11-16]$.

Diversification is a potential benefit to silvopasture, as well $[5,17,18]$. Spreading investments over multiple commodities (timber, livestock) to minimize marketplace risks appeals to landowners with diverse investment portfolios. Furthermore, services such as hunting leases, carbon credits, water quality improvements, biodiversity, and other ecosystem payment options can provide supplemental income that can help generate revenue and minimize these risks rather than relying on one single commodity product $[5,14,17]$. Moreover, the timing of revenue generation is attractive to some landowners-livestock and forage offer annual income, while timber provides a long-term investment $[5,18]$. Finally, silvopasture is seen as both socially acceptable and aesthetically pleasing [4], satisfying conservationists and animal rights advocates with the incorporation of ecologically diverse forests $[6,16]$. These silvopasture systems could contribute to improved animal health and welfare and, thus, healthier food for humans [19].

\subsection{Southeastern U.S.A. Systems}

In the southeastern United States, loblolly pine (Pinus tadea L.) is the most planted softwood species [5]. Loblolly provides cover, food, and habitat for a variety of wildlife species. In states like Mississippi, softwood timber production is a major land use, comprising almost $45 \%$ of the state's land base [20]. Due to silvicultural management and genetic advancements, loblolly has realized faster growth rates, volumetric yields, and disease resistance [21], making it a prime candidate for silvopasture systems.

Silvopasture typically includes the production of warm- or cool-season forages that can be sold for hay or used for grazing [22]. Warm-season forages are often cultivated for 
their faster growth rates and higher yields. For example, bahiagrass (Paspalum notatum Flueggé var. notatum) and little bluestem (Schizachyrium scoparium (Michx.) Nash) are perennial warm-season forage grasses that typically grow faster than cool-season forages [23]. However, both warm- and cool-season forages provide benefits to their ecosystem that range from pollinator attraction, wildlife habitat, and erosion mitigation [24].

Previous agroforestry research at the Center for Environmental Farming Systems (CEFS) located near Goldsboro, North Carolina, U.S., evaluated an alley cropping system with three tree species (loblolly pine, longleaf pine (Pinus palustris Mill.), and cherrybark oak (Quercus pagoda) and two agricultural crops, corn (Zea mays L.) and soybeans (Glycine $\max ($ L.) Merr.), in alternating years for six years [25], on a 7 ha field, before conversion to a beef silvopasture site. The researchers noted that, in theory, average state yields for corn and beans should provide greater returns than timber. However, frequent floods and droughts during the first six years usually resulted in negative crop returns, while the planted trees continued to increase in volume and value [25].

Bruck et al. [8] extended the CEFS economic capital budgeting analysis for silvopasture and found that beef cattle returns exceeded southern pine returns, due in part to high beef prices in 2017, but both offered reasonable returns using a $4 \%$ real discount rate. The pure livestock regime had a net present value (NPV) of USD 3194 per ha (USD 1293 per ac) and a land expectation value (LEV) of USD 5113 per ha (USD 2070 /ac) at a 4\% real discount rate. At the same real discount rate, the per-ha NPV and LEV values for monoculture loblolly pine were USD 2742 and USD 4389 per ha (USD 1110 and USD 1777 per ac), respectively. The NPV associated with loblolly pine/silvopasture returns and production of warm-season bermudagrass (Cynodon dactylon Pers.) was USD 855 per ha (USD 346/ac), but growing warm-season switchgrass (Panicum virgatum L.) increased NPV to USD 1104 per ha (USD $447 /$ ac). Loblolly pine silvopasture with a cool-season grass such as fescue (Festuca spp.) resulted in an NPV of USD 1583 per ha (USD 641 /ac), and growing clover (Trifolium spp.) as the forage generated an NPV to USD 1472 per ha (USD 596/ac) [8]. These results reflect that the site was relatively productive for trees but was a poor site for pasture.

\subsection{Objectives}

In 2012, a new 2 ha (5 ac) silvopasture field trial was established at CEFS to assess timber and forage production in silvopastures where loblolly pine had been planted at several different spacings to eventually provide a silvopasture system to support grazing by dairy cattle. Cattle have not yet been introduced in this field trial. As such, our objective for this analysis focused on an examination of the current status of this trial after six growing seasons and to estimate future financial returns predicted from continued management of the site as a loblolly pine or grass monoculture or as a silvopasture producing both timber and forage. Thus, these alley cropping analyses serve as proxy for the much more complex livestock systems that are planned for the site in the future.

\section{Experimental Design}

We assessed the bioeconomic relationship between timber and forage based on different blocks of tree spacings and prospective pasture grasses. Tree inventories, soil testing, and computer modeling were all used to determine the financial implications of intercropping timber and warm-season grasses. Field observations and soil analysis indicated that the research site is relatively degraded, making the field site less suitable for conventional grazing forages. Using secondary literature, farm records, and managers' opinions, two forages, switchgrass and big bluestem (Andropogon gerardii Vitman), were selected and modeled for our research. For reference, all the field trial plantings and measurements were conducted in standard local English measurement units but are converted to SI metric units for this paper.

This project is established on the CEFS/Cherry Farm, which is owned by the State of North Carolina and managed jointly by the North Carolina Department of Agriculture and 
Consumer Services Research Stations Division, and North Carolina State University. The site is located in the Coastal Plain physiographic province, near the Neuse River, one of the major North Carolina River systems traversing the Piedmont of North Carolina through the Coastal Plain to the Atlantic Ocean. The entirety of the project site occurs on Leaf loam (Le) soils, which are deep, poorly drained, fine, mixed, active, thermic Typic Albaquults that were derived from clayey marine deposits. The site has a warm temperate climate and averages about $1220 \mathrm{~mm}$ (48 inches) of rain per year, well-distributed throughout the year, but with the most in the summer months.

The research site had previously been cultivated under rotations of corn and soybeans. The new demonstration consists of loblolly pine planted at four different density treatments: $3.0 \times 3.0 \mathrm{~m}$; 1074 trees per ha $(10 \times 10 \mathrm{ft}$; 435 trees per ac), $2.4 \times 3.0 \mathrm{~m} ; 1346$ trees per ha $(8 \times 10 \mathrm{ft}$; 545 trees per ac), $2.4 \times 2.4 \mathrm{~m} ; 1682$ trees per ha $(8 \times 8 \mathrm{ft}$; 681 trees per ac), and $1.8 \times 3.0 \mathrm{~m}$; 1793 trees per ha $(6 \times 10 \mathrm{ft} ; 726$ trees per ac). Trees were planted in bands consisting of three rows of trees per band, and with a $12 \mathrm{~m}(40 \mathrm{ft})$ grass alley located between each tree band. Thus, after accounting for area occupied by the $12 \mathrm{~m}$ grass alley, the per-ha densities of planted loblolly were roughly half of that stated above for each spacing. The forage component of this silvopasture is currently dominated by sow thistle (Sonchus spp.), red clover (Trifolium pratense), and little bluestem. Using secondary literature, farm records, and CEFS' farm managers' preferences, switchgrass and big bluestem, two common warm-season grasses planted in the southeastern U.S., were selected as grasses to use for modeling forage production in this research.

As noted, this alley cropped field trial is transitioning into a dairy cattle silvopasture system. Timber and naturally occurring grasses have already been established. In the future, dairy cattle are scheduled to begin rotational grazing the site to implement a silvopasture system. For this research, we estimated economic returns for each timber, forage, and alley cropping system and various tree spacing, alley spacing, and tree and grass competition assumptions.

\subsection{Field Inventories and Production Data}

In 2018, when the trees were 6 years old, a total census of trees within the silvopasture trial site was conducted. Tree height (ft), $\mathrm{dbh}(4.5 \mathrm{ft})$, and crown ratio (percent) were collected and recorded for each tree. Tree heights and diameters were collected using a dbh tape and vertex hypsometer. Field data were entered and projected using several individual tree growth and yield models (FVS, PTADEA, ALLEY 2.0) [26-28], which produced yield estimations for woody biomass. Of the three models, ALLEY 2.0, which is an alley cropping financial model, including growth and yield projections, was chosen to provide future yield projections for timber rotations of 25 years and a thinning in year 12 . To synchronize model growth rates with measured field data, Alley 2.0 was calibrated to match field data with computer simulated outputs at age 6 for the trees.

Botanical samples were taken from 1-meter square field plots randomly located across the study site to characterize and quantity the forage present in the silvopasture trial six growing seasons post-establishment, and naturalist's notes were taken in the survey. Representative plants from the field were collected and pressed to preserve and identify plant species from the site. Inventory notes were also made regarding species composition and species abundance at the research site.

Based on this preliminary analysis, it was determined that the native forage was of poor quality. To model a more productive alley cropping system, big bluestem and switchgrass yields were estimated for the site based on soil analysis, literature review, and consultation with farm experts and staff at CEFS. These varied somewhat by year but averaged about 12.5 metric tons/ha/yr (5.6 tons/ac/yr) per year for big bluestem and 10.3 metric tons/ha/yr (4.6 tons/ac/yr) for switchgrass. 


\subsection{Timber and Forage Competition Modeling}

In addition to modeling timber and forage growth rates, competitive interactions between timber and forage were analyzed to determine how competition affects forage yield and overall financial returns of an alley cropping system. Three scenarios were chosen as a proxy to assess the potential biological interactions between forage and timber, based on competition functions provided in Frey et al. [28]: competitive (pessimistic), quasi-complementary (optimistic), and no interaction.

The pessimistic and optimistic production functions were expressed as a proportion of the expected yield under noncompetitive conditions using length of live crown as the variable that determines the reduction in yield [28]. A pessimistic interaction suggests that competition between timber and forage is intense. Over time, canopy closure will reduce forage yield, leading to reductions in overall revenue, depending on the stand age and planting densities.

The optimistic scenario suggests low levels of competition between timber and forage. It is less competitive than the pessimistic scenario and predicts increases in forage production at certain years. This assumption comes from the possibility that, at various stages in a timber rotation, particularly at the start, forages can receive a complementary benefit from canopy cover $[29,30]$.

The last modeling scenario was that of no interaction scenario. This suggests that timber and forage are competitively independent. Neither species receives any biological penalty or benefit from being cultivated together. These three production interactions served as the basis for the economic analyses and the overall financial revenue of each alley cropping spacing.

\subsection{Economic Analysis}

Costs associated with tree planting and establishment were derived from UDSA tree planting data [31], which lists average establishment cost as being roughly USD 250/ac. Due to the demonstration site being approximately $50 \%$ timber and $50 \%$ forage, USD $125 /$ ac was selected to plant establish timber. Forage establishment costs were retrieved using the 2020 NCSU Crop Science Farm Workbook [32]. Switchgrass establishment and re-establishment cost was estimated to be USD 420/ha (USD 170/ac) along with a USD 173/ha/yr (USD 70/ac/yr) annual maintenance cost. Big bluestem establishment had an estimated cost of USD 716 per ha (USD 290/ac) along with a USD 260/ha/yr (USD 105/ac/yr) annual maintenance cost. A one-time USD 474 per ha (USD 192/ac) reestablishment cost in year 12 was implemented for bluestem, as well [32].

For timber prices, average third quarter 2019 stumpage values from Forest2Market (F2M) were used to determine timber revenues [33]. Stumpage values are assumed as net revenues, excluding the costs of logging and management. Per-green-ton stumpage values for each product class were as follows: pulpwood USD 9.83/metric ton (USD 8.92/ short ton), chip-n-saw USD 18.18/metric ton, (USD 16.50/short ton), and sawtimber USD $30.25 /$ metric ton (USD 27.44/short ton). For this model, all forages are sold as baled hay. Switchgrass was valued at USD 38.58/ metric ton (USD 35/short ton) and bluestem at USD 44.09/metric ton (USD 40/short ton) based on 2020 USDA data averages [34] and anticipated forage quality.

The capital budgeting criteria of NPV, LEV, and internal rate of return (IRR) were used to calculate the financial returns for all systems. NPV refers the total value of an asset, discounting all future costs and revenues and bringing them to the present, using a given discount rate. LEV refers to the value of an investment if it were repeated in perpetuity. IRR is the annual percentage rate of return, which, if used as a discount rate, would make the NPV and LEV equal to zero [35]. As an example, an LEV of USD 2700/ha indicates that, based on projected costs, revenues, and the given discount rate, the land would be worth USD 2700/ha if managed with identical rotations in perpetuity.

NPVs and LEVs were calculated using a $4 \%$ discount rate based on timber harvest volumes with the ALLEY 2.0 package and computer growth simulations, 2019 planting 
costs, and third quarter 2019 timber prices. We calculated the optimal timber rotations that would maximize the LEV for each tree planting density. We then used ALLEY 2.0 to analyze returns for the optimistic, pessimistic, and noninteractive tree-grass competition scenarios and for different widths of the grass alleys between bands of trees $-12 \mathrm{~m}, 24 \mathrm{~m}$, and $36.5 \mathrm{~m}(40 \mathrm{ft}, 80 \mathrm{ft}$, and $120 \mathrm{ft})$.

A common rotation age of 25 years was used for timber monocultures, grass monocultures, and for the silvopasture system to maintain comparability with earlier analyses on the other silvopasture site at CEFS. The rotation of 25 years corresponds well with most intensive forest land management practices in the region. In fact, similar to intensive pine plantation management, silvopasture systems provide several of the biological growth benefits that can result from regular control of competition vegetation, establishment on relatively good soils for trees, and wide spacings that allow large crowns and leaf/needle capture for fast woody biomass production. However, these same growth benefits could lead to long-term degradation in wood quality due to trees bending at the edge of rows or a high proportion of knots caused by many large limbs. More research is needed concerning the timber quality among trees grown in silvopasture systems, but such work is beyond the scope of this stage of our research efforts.

\section{Results}

\subsection{Botanical Inventory and Biodiversity}

Notes taken from field plots indicated that vegetation contained within the research site, aside from planted loblolly pine, consisted of a combination of woody and herbaceous species. Woody and herbaceous species such as poison ivy (Toxicodendron radicans), sweet gum (Liquidambar styriciflua), horseweed (Erigeron canadensis), and yellow jessamine (Gelsemium sempervirens) were found in the understory of the tree bands. Sow thistle, red clover, and little bluestem dominated in the forage alleys. After six growing seasons, understory plant diversity was higher in the tree bands than in the pasture alleys. When inventorying the site, field crews observed that plant diversity increased near the edges of the tree bands and pasture strips, which were exposed to full sunlight, having noticeably more vines, shrubs, and herbaceous regeneration. While the plant diversity increased within the trees, the species there were not as good for livestock forage.

A variety of wildlife species were documented at the site by tracks, scat, graze marks, and sightings. Deer, shrews, moles, snakes, and various birds of prey were observed, perhaps drawn to more a diverse ecosystem. Based on our observations, the cover and forage provided by mix of trees and pasture led to more diverse plant species. There appeared to be more plant and animal species diversity in this field trial and in the prior silvopasture demonstration area compared to other open pasture areas at the CEFS site. Future research could be performed to examine this hypothesis.

\subsection{Tree Field Data}

As noted, field data for tree heights, diameters, and individual tree mortality were collected for every tree within each tree band. Average diameter at breast height (dbh) for the $2.4 \times 2.4 \mathrm{~m}(8 \times 8 \mathrm{ft})$ spacing averaged $14.7 \mathrm{~cm}(5.8 \mathrm{in}) ; 16.1 \mathrm{~cm}(6.5 \mathrm{in})$ for the $2.4 \times 3.0 \mathrm{~m}(8 \times 10 \mathrm{ft}) ; 16.1 \mathrm{~cm}(6.5 \mathrm{in})$ for the $3.0 \times 3.0 \mathrm{~m}(10 \times 10 \mathrm{ft})$; and $17 \mathrm{~cm}(6.7 \mathrm{in})$ for the $1.8 \times 3.0 \mathrm{~m}(6 \times 10 \mathrm{ft})$ (Figure 1$)$. Average height for the $2.4 \times 2.4 \mathrm{~m}(8 \times 8 \mathrm{ft}) \mathrm{spacing}$ averaged $7.3 \mathrm{~m}(24 \mathrm{ft}) ; 8.2 \mathrm{~m}(27 \mathrm{ft})$ for the $2.4 \times 3.0 \mathrm{~m}(8 \times 10 \mathrm{ft}) ; 7.6 \mathrm{~m}(25 \mathrm{ft})$ for the $3.0 \times 3.0 \mathrm{~m}(10 \times 10 \mathrm{ft})$; and $8.2 \mathrm{~m}(27 \mathrm{ft})$ for the $1.8 \times 3.0 \mathrm{~m}(6 \times 10 \mathrm{ft})($ Figure 2$)$. 


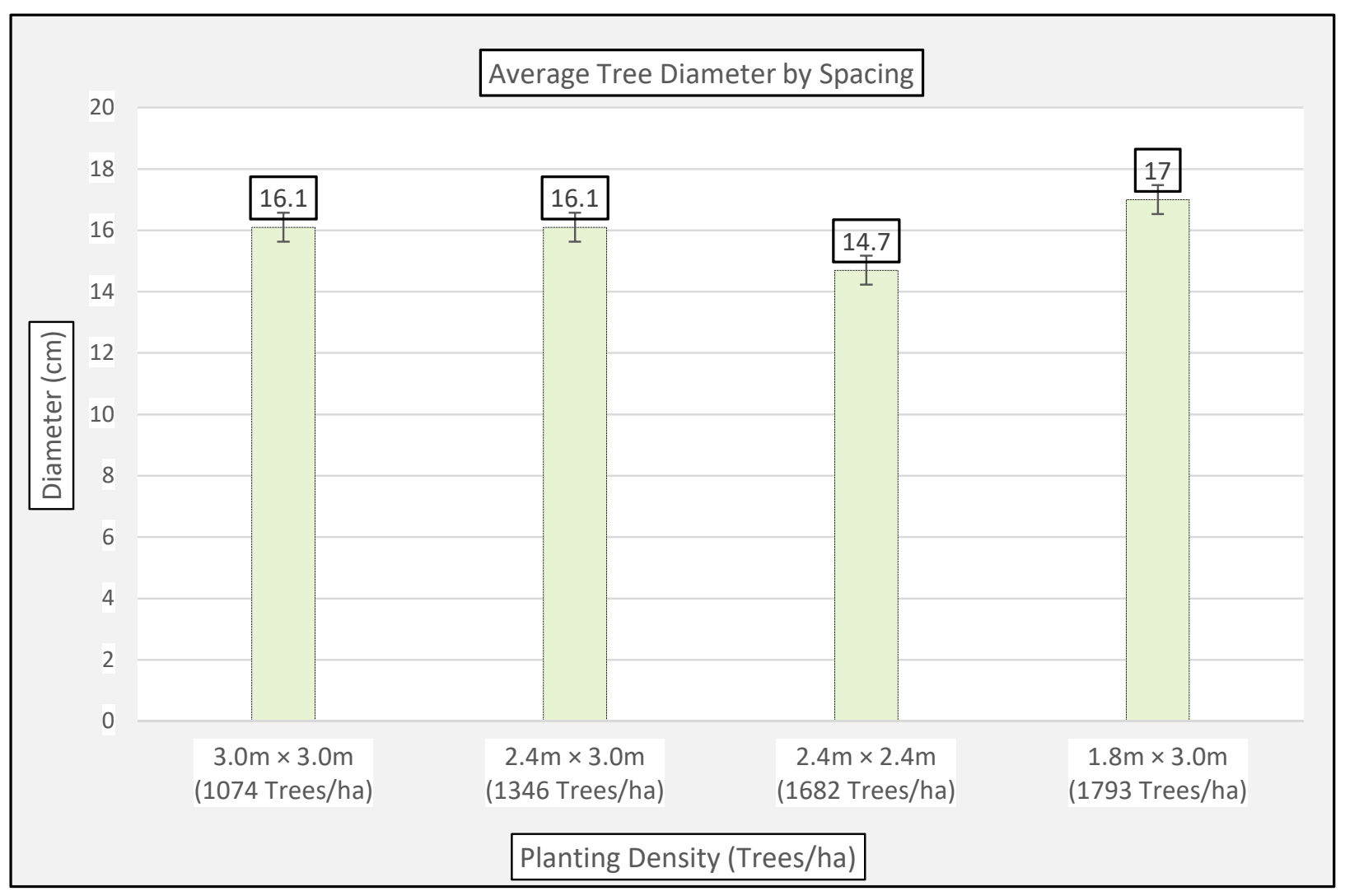

Figure 1. Average Tree Diameter for $12 \mathrm{~m}$ Wide Alley Cropped Density Treatments.

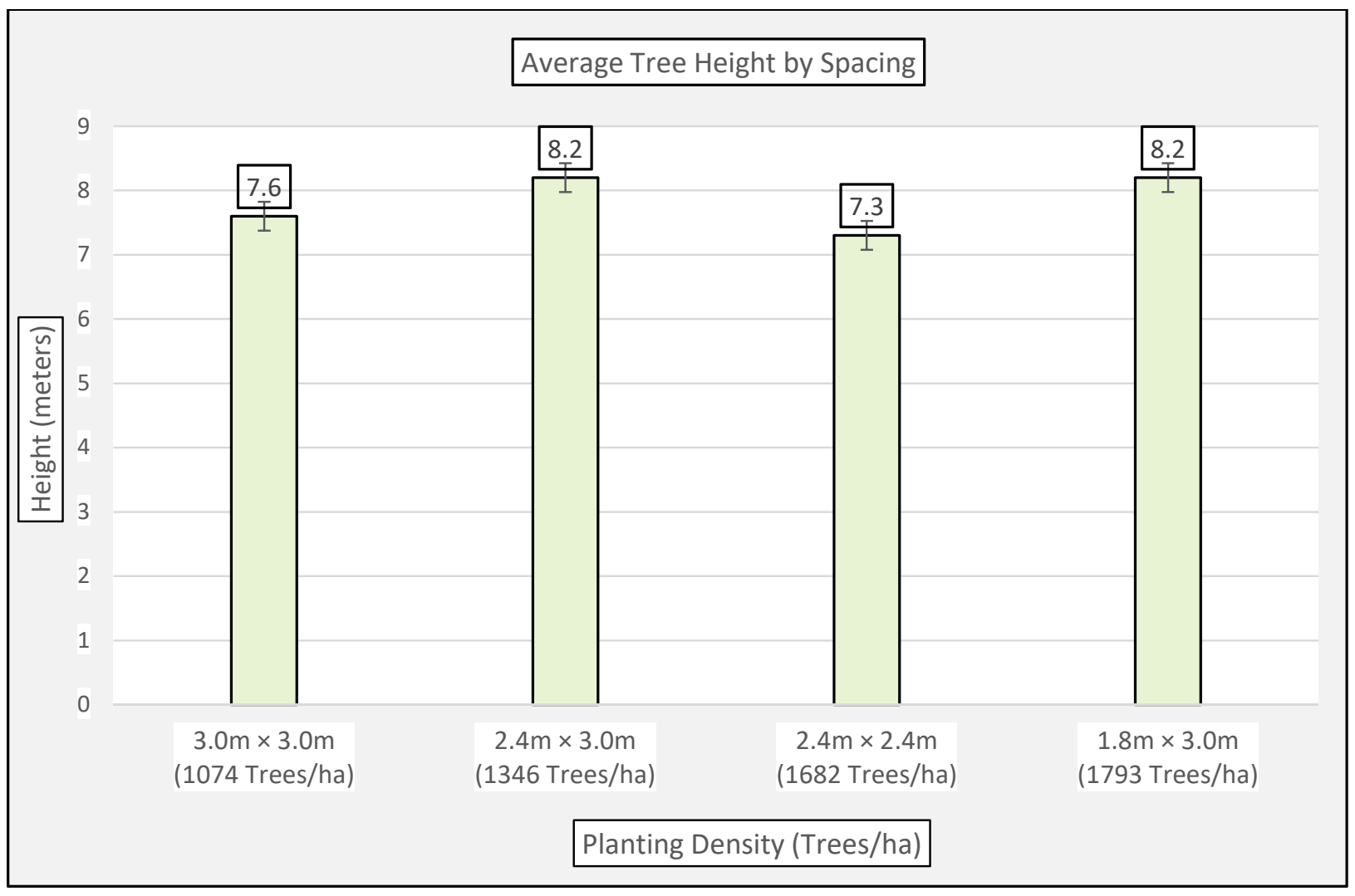

Figure 2. Average Tree Heights for $12 \mathrm{~m}$ Wide Alley Cropped Density Treatments. 
Tukey's HSD tests were conducted to investigate statistical differences in height and diameters. A Tukey's HSD test is a statistical test similar to that of two-tailed T-test with a $95 \%$ confidence interval. The only difference is that mean variation is also measured. In other words, a Tukey's HSD test determines both statistical significance and mean variation with a single test.

No significant differences were found among heights between the $2.4 \times 2.4 \mathrm{~m}(8 \times 8 \mathrm{ft})$ and $3.0 \times 3.0 \mathrm{~m}(10 \times 10 \mathrm{ft})$ or the $2.4 \times 3.0 \mathrm{~m}(8 \times 10 \mathrm{ft})$ and $3.0 \times 3.0 \mathrm{~m}(10 \times 10 \mathrm{ft})$ spacings at a $95 \%$ family-wise confidence level. Significant differences were found between the $1.8 \times 3.0 \mathrm{~m}(6 \times 10 \mathrm{ft})$ and $3.0 \times 3.0 \mathrm{~m}(10 \times 10 \mathrm{ft}), 1.8 \times 3.0 \mathrm{~m}(6 \times 10 \mathrm{ft})$ and $2.4 \times 3.0 \mathrm{~m}$ $(8 \times 10 \mathrm{ft}), 2.4 \times 2.4 \mathrm{~m}(8 \times 8 \mathrm{ft})$ and $1.8 \times 3.0 \mathrm{~m}(6 \times 10 \mathrm{ft})$, and the $2.4 \times 2.4 \mathrm{~m}(8 \times 8 \mathrm{ft})$ and $2.4 \times 3.0 \mathrm{~m}(6 \times 10 \mathrm{ft})$. On average, the $1.8 \times 3.0 \mathrm{~m}(6 \times 10 \mathrm{ft})$ spacing was approximately $0.6 \mathrm{~m}$ taller than the $2.4 \times 3.0 \mathrm{~m}(8 \times 10 \mathrm{ft})$ and $1.8 \times 3.0 \mathrm{~m}(6 \times 10 \mathrm{ft})$. The $2.4 \times 2.4 \mathrm{~m}$ $(8 \times 8 \mathrm{ft})$ spacing had the shortest mean variation, being approximately one meter shorter than the $1.8 \times 3.0 \mathrm{~m}(6 \times 10 \mathrm{ft})$ and $2.4 \times 3.0 \mathrm{~m}(8 \times 10 \mathrm{ft})$ spacings (Figure 3$)$.

$1.8 \mathrm{~m} \times 3.0 \mathrm{~m}-3.0 \mathrm{~m} \times 3.0 \mathrm{~m}$

$1.8 \mathrm{~m} \times 3.0 \mathrm{~m}-2.4 \mathrm{~m} \times 3.0 \mathrm{~m}$

$2.4 \mathrm{~m} \times 2.4 \mathrm{~m}-3.0 \mathrm{~m} \times 3.0 \mathrm{~m}$

$2.4 \mathrm{~m} \times 3.0 \mathrm{~m}-3.0 \mathrm{~m} \times 3.0 \mathrm{~m}$

$2.4 \mathrm{~m} \times 2.4 \mathrm{~m}-1.8 \mathrm{~m} \times 3.0 \mathrm{~m}$

$2.4 \mathrm{~m} \times 2.4 \mathrm{~m}-2.4 \mathrm{~m} \times 3.0 \mathrm{~m}$

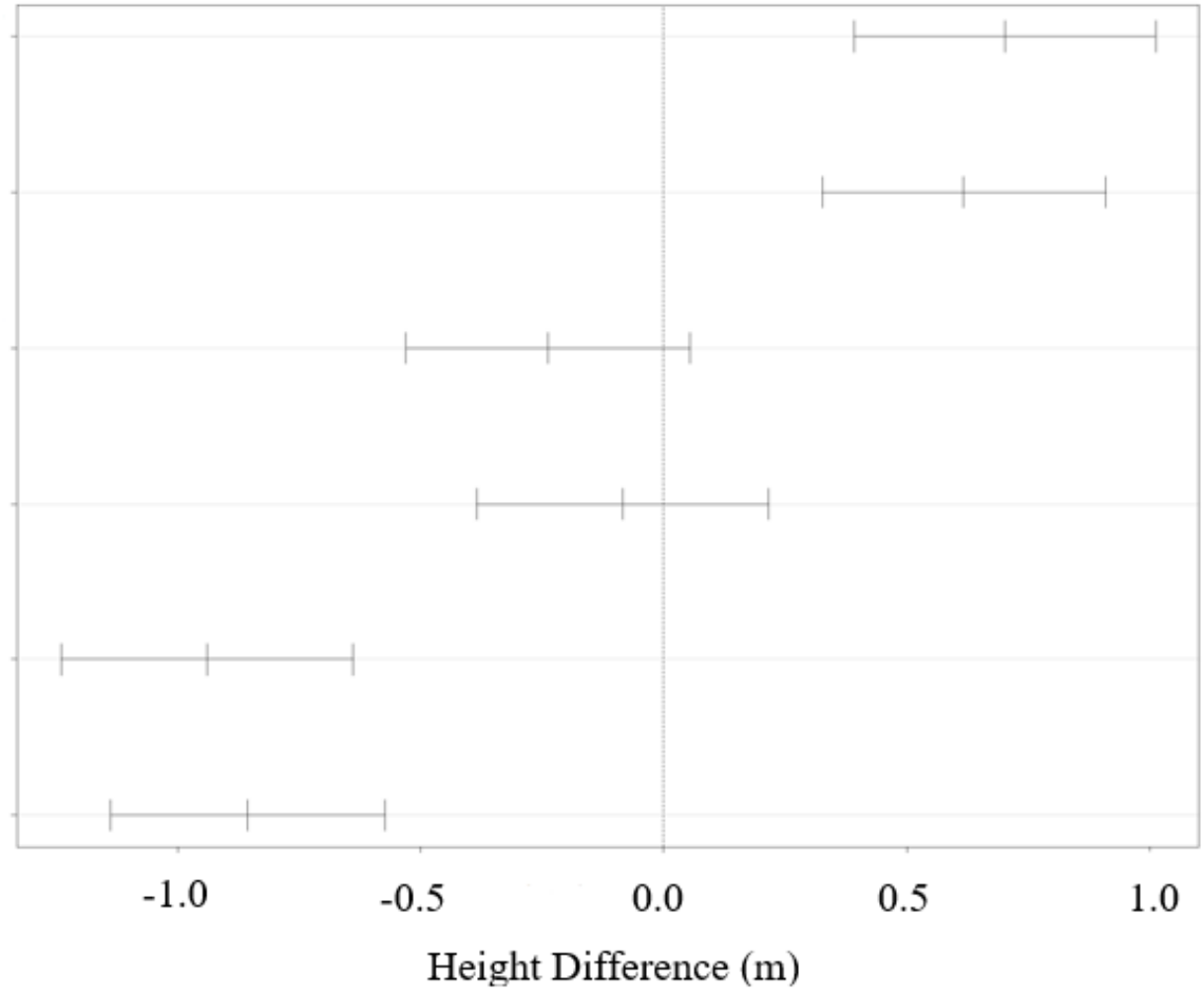

Figure 3. Tukey HSD Test of Tree Height Differences.

There were no statistical differences in diameter between the $1.8 \times 3.0 \mathrm{~m}(6 \times 10 \mathrm{ft})$ and $3.0 \times 3.0 \mathrm{~m}(10 \times 10 \mathrm{ft})$ spacings; no difference between the $1.8 \times 3.0 \mathrm{~m}(6 \times 10 \mathrm{ft})$ and $2.4 \times 3.0 \mathrm{~m}(8 \times 10 \mathrm{ft})$; and no difference between the $2.4 \times 3.0 \mathrm{~m}(8 \times 10 \mathrm{ft})$ and $3.0 \times 3.0 \mathrm{~m}$ $(10 \times 10 \mathrm{ft})$. Statistical differences were found in the $2.4 \times 2.4 \mathrm{~m}(8 \times 8 \mathrm{ft})$ spacing and $3.0 \times 3.0 \mathrm{~m}(10 \times 10 \mathrm{ft}), 2.4 \times 2.4 \mathrm{~m}(8 \times 8 \mathrm{ft})$ and $2.4 \times 3.0 \mathrm{~m}(6 \times 10 \mathrm{ft})$, and $2.4 \times 2.4 \mathrm{~m}$ $(8 \times 8 \mathrm{ft})$ and $1.8 \times 3.0 \mathrm{~m}(6 \times 10 \mathrm{ft})$ spacings (Figure 4$)$. 


\section{Tukey HSD Test (Diameter)}

$1.8 \mathrm{~m} \times 3.0 \mathrm{~m}-3.0 \mathrm{~m} \times 3.0 \mathrm{~m}$

$1.8 \mathrm{~m} \times 3.0 \mathrm{~m}-2.4 \mathrm{~m} \times 3.0 \mathrm{~m}$

$2.4 \mathrm{~m} \times 2.4 \mathrm{~m}-3.0 \mathrm{~m} \times 3.0 \mathrm{~m}$

$2.4 \mathrm{~m} \times 3.0 \mathrm{~m}-3.0 \mathrm{~m} \times 3.0 \mathrm{~m}$

$2.4 \mathrm{~m} \times 2.4 \mathrm{~m}-1.8 \mathrm{~m} \times 3.0 \mathrm{~m}$

$2.4 \mathrm{~m} \times 2.4 \mathrm{~m}-2.4 \mathrm{~m} \times 3.0 \mathrm{~m}$

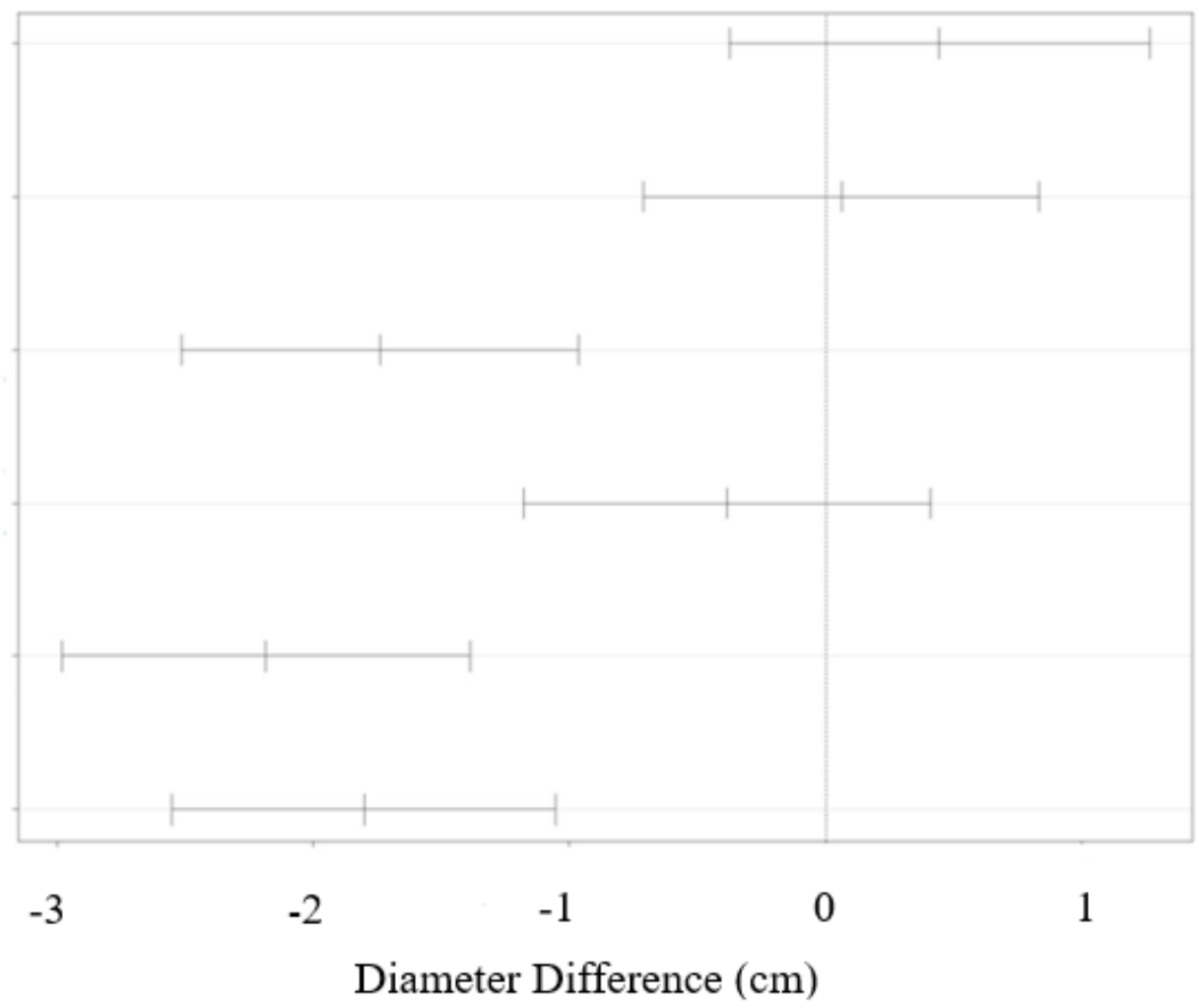

Figure 4. Tukey HSD Test of Tree Diameter Differences.

\subsection{Timber Yields and Projected Growth Rates}

Using the field measurements at age 6 to calibrate the model, ALLEY 2.0 projected that, over a rotation period of 25 years, timber monocultures established at a $2.4 \times 2.4 \mathrm{~m}$ spacing will yield approximately 18.6 metric tons/ha/yr; a $2.4 \times 3.0 \mathrm{~m}$ monoculture, approximately 16.0 metric tons/ha/yr; a $3.0 \times 3.0 \mathrm{~m}$ monoculture, 16.9 metric tons/ha/yr; and a $1.8 \times 3.0 \mathrm{~m}$ monoculture, 17.4 metric tons $/ \mathrm{ha} / \mathrm{yr}$ (Figure 5). For an alley cropped system with a $12 \mathrm{~m}(40 \mathrm{ft})$ pasture between tree bands, ALLEY 2.0 predicted that a $2.4 \times 2.4 \mathrm{~m}$ $(8 \times 8 \mathrm{ft})$ tree spacing will yield approximately 13.0 metric tons/ha/yr; a $2.4 \times 3.0 \mathrm{~m}$ $(8 \times 10 \mathrm{ft})$ spacing will yield 11.9 metric tons $/ \mathrm{ha} / \mathrm{yr}$; a $3.0 \times 3.0 \mathrm{~m}(10 \times 10 \mathrm{ft})$ spacing, 11.2 metric tons/ha/yr; and a $1.8 \times 3.0 \mathrm{~m}$ spacing $(6 \times 10 \mathrm{ft}), 12.8$ metric tons/ha/yr (Figure 5). 


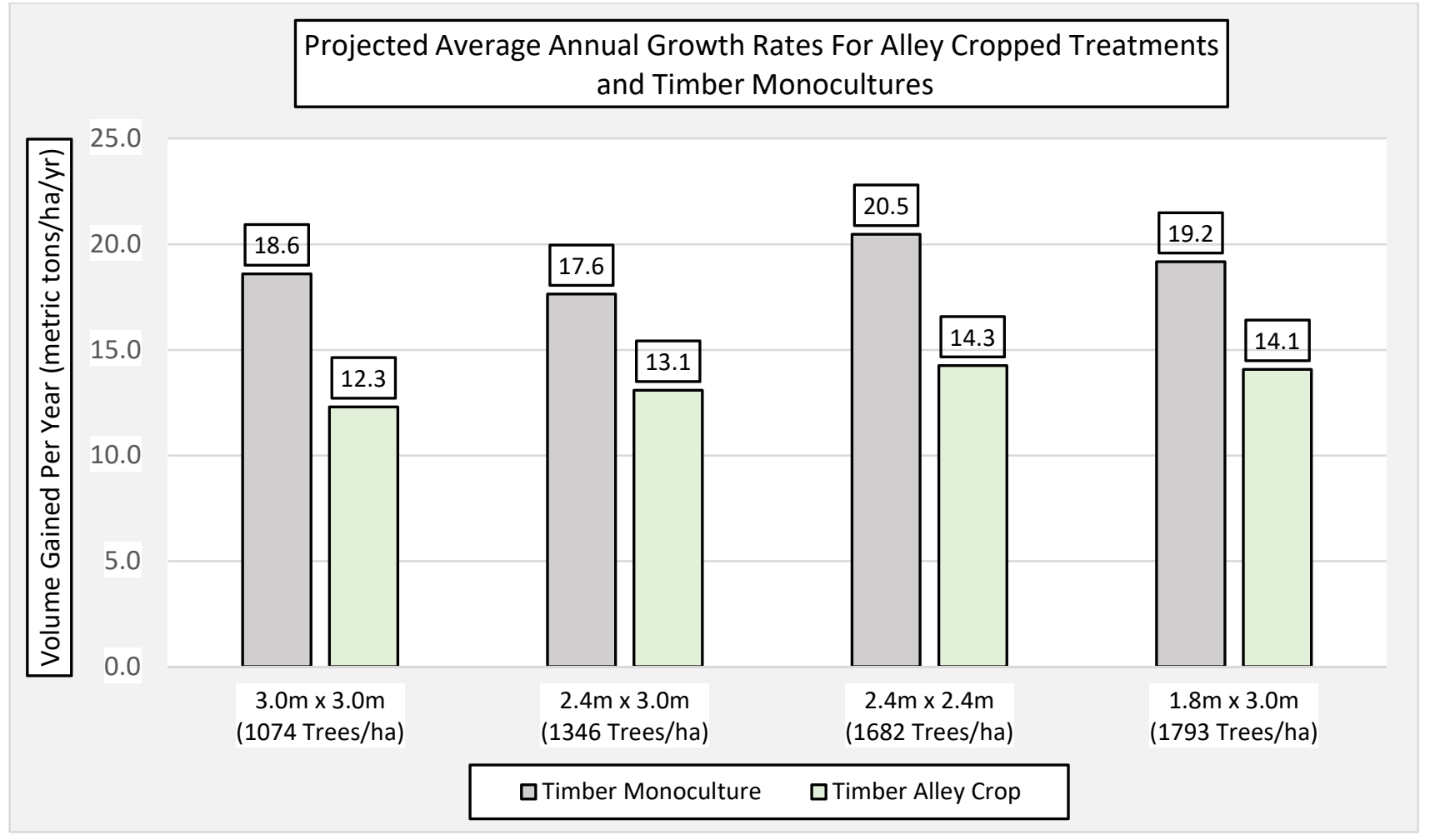

Figure 5. Average Annual Growth and Yield Rates for Timber in a $12 \mathrm{~m}$ Wide Alley Cropped and Timber Monoculture Systems.

\subsection{Forage and Timber Monoculture Economic Returns}

Based on third quarter 2019 stumpage values, timber was estimated to have NPVs between USD 3196 per ha (USD 1294 per ac) for the $2.4 \times 3.0 \mathrm{~m}$ spacing and USD 3552 per ha (USD 1438 per ac) for the $2.4 \times 2.4 \mathrm{~m}$ spacing. IRRs ranged from $12 \%$ to $13 \%$ for timber monocultures at the optimal rotation ages (Table 1). Switchgrass and big bluestem from a hay cropping system for 25 years were projected to generate USD 2581 per ha (USD 1045 per ac) and USD 1853 per ha (USD 750 per ac), respectively, along with large IRRs of $54 \%$ and $17 \%$ (Table 2). Big bluestem did have higher average yields per ha (12.5 tons/ha/yr) and better prices than switchgrass $(10.3 / \mathrm{ha} / \mathrm{yr})$ but had greater costs for establishment and maintenance than switchgrass. These net yields, costs, and product prices led to the better switchgrass present values.

Table 1. Capital budgeting results for monoculture timber investments per ha, 4\% discount rate, USD, 2019.

\begin{tabular}{cccccc}
\hline Spacing (feet) & Establishment Cost & NPV & Optimal SEV & Optimal SEV Age & IRR \\
\hline $3.0 \mathrm{~m} \times 3.0 \mathrm{~m}$ & USD 703.46 & USD 3458.84 & USD 5688.29 & 22 & $13.2 \%$ \\
$2.4 \mathrm{~m} \times 3.0 \mathrm{~m}$ & USD 725.19 & USD 3196.23 & USD 5171.22 & 23 & $12.0 \%$ \\
$2.4 \mathrm{~m} \times 2.4 \mathrm{~m}$ & USD 752.07 & USD 3550.85 & USD 5865.68 & 21 & $12.2 \%$ \\
$1.8 \mathrm{~m} \times 3.0 \mathrm{~m}$ & USD 760.96 & USD 3295.84 & USD 5446.99 & 21 & $12.2 \%$ \\
\hline
\end{tabular}

Note: 1 ha $=2.47$ ac.

Table 2. Capital budgeting results for planting warm-season grasses per ha, 4\% discount rate, USD, 2019.

\begin{tabular}{cccccc}
\hline Forage Type & Establishment Cost & Maintenance Cost per Year & NPV & SEV & IRR \\
\hline Switchgrass & USD 419.90 & USD 172.90 & USD 2581.59 & USD 419.90 & $54.0 \%$ \\
Big Bluestem & USD 864.50 & USD 259.35 & USD 1851.34 & USD 864.50 & $17.5 \%$ \\
\hline
\end{tabular}


In general, all these investment returns as measured by NPV and LEV were greater for timber than for hay. However, forage had higher IRRs. These differences could be attributed to the fact that the cash flow returns at a low discount rate of $4 \%$ were higher for timber, but those incomes were received farther out in the future. Hay, however, generated annual incomes and so yielded a higher rate of return, which is likely to be more attractive for farmers.

\subsection{Integrated Alley Cropping Returns}

The integrated returns for mixed grass and tree alley crops for different tree spacings, alley widths, and competition assumptions are shown in Tables 3 and 4 for switchgrass and big bluestem grasses. For the base switchgrass scenario of $12 \mathrm{~m}$ alleys that was planted on the field trial, the greatest NPV (USD 3826/ha) occurred with the no interaction assumption, with $1.8 \times 3.0 \mathrm{~m}$ spacing (1793 trees per ha), followed by $2.4 \times 3.0 \mathrm{~m}(1346 \mathrm{TPH})$ and $2.4 \times 2.4 \mathrm{~m}(1683 \mathrm{TPH})$ at about USD 3750/ha and with largest spacing of $3.0 \times 3.0 \mathrm{~m}$ (USD 3356/ha). For the $12 \mathrm{~m}$ alleys, NPVs were consistently less for the optimistic and pessimistic scenarios of by about USD 400 to USD 1600 per ha, depending on the spacing and assumption about tree and grass competition. This suggests that, for the narrow alleys, having more trees, which have higher monoculture returns than grass, will generate higher financial returns, despite the shade and nutrient competition. This outcome was also the same for big bluestem narrow alleys, which had even greater financial advantages of no interaction compared to the optimistic and pessimistic scenarios.

Table 3. Switchgrass Alley-Cropped Competition Modeling Displaying Potential NPV Revenues (USD/ha) in Response to Tree Density and Competition over 25 years, using 4\% discount rate, USD, 2019.

\begin{tabular}{cccc}
\hline & \multicolumn{2}{c}{ Switchgrass Alley-Cropped NPV Projections (USD/ha) } \\
\hline Tree Spacing (m) & NPV (12 m Alleyway) & No Interaction \\
$3.0 \mathrm{~m} \times 3.0 \mathrm{~m}$ & Optimistic & USD 3356.09 \\
$2.4 \mathrm{~m} \times 3.0 \mathrm{~m}$ & USD 2429.99 & USD 2947.38 & USD 3752.62 \\
$2.4 \mathrm{~m} \times 2.4 \mathrm{~m}$ & USD 2462.84 & USD 2988.43 & USD 3741.73 \\
$1.8 \mathrm{~m} \times 3.0 \mathrm{~m}$ & USD 2451.92 & USD 2977.54 & USD 3825.59 \\
& USD 2174.98 & USD 2201.91 & No Interaction \\
Tree $\mathrm{Spacing} \mathrm{(m)}$ & Pessimistic & NPV (24 m alleyway) & USD 2926.97 \\
$3.0 \mathrm{~m} \times 3.0 \mathrm{~m}$ & USD 2428.38 & USD 3857.28 & USD 3170.94 \\
$2.4 \mathrm{~m} \times 3.0 \mathrm{~m}$ & USD 2459.97 & USD 3760.92 & USD 3433.84 \\
$2.4 \mathrm{~m} \times 2.4 \mathrm{~m}$ & USD 2397.80 & USD 3449.03 & USD 3290.86 \\
$1.8 \mathrm{~m} \times 3.0 \mathrm{~m}$ & USD 2194.22 & NSD 2799.35 (36.5 m alleyway) & No Interaction \\
Tree $\mathrm{Spacing} \mathrm{(m)}$ & Pessimistic & USD 3353.25 & USD 2511.20 \\
$3.0 \mathrm{~m} \times 3.0 \mathrm{~m}$ & USD 2192.10 & USD 3526.07 & USD 2842.25 \\
$2.4 \mathrm{~m} \times 3.0 \mathrm{~m}$ & USD 2278.33 & USD 3744.67 & USD 3010.07 \\
$2.4 \mathrm{~m} \times 2.4 \mathrm{~m}$ & USD 2469.21 & USD 3235.18 & USD 2982.82 \\
$1.8 \mathrm{~m} \times 3.0 \mathrm{~m}$ & USD 2111.33 & & \\
\hline
\end{tabular}

Note: 1 ha $=2.47$ ac.

However, this pattern of independent tree and grass growth (no interaction) and the most trees per ha being superior did not hold for the wider alleys. With the $24 \mathrm{~m}$ and $36.5 \mathrm{~m}$ alleys, the optimistic scenario with some complementary tree-grass interaction in the early years led to the greatest NPVs. Furthermore, wider tree spacing and less trees per ha also had greater NPVs than denser tree stands in the rows. The pessimistic assumption of intense tree and grass competition remained the worse alternatives for all tree spacings but did not differ much regardless of tree spacing or alley width.

Overall, these alley cropping/silvopasture results indicate that discounted present value returns did not differ greatly among any of the in-row tree spacings examined at less than USD 500 per ha for any given alley width. The possible differences due to alley 
width appeared to be more variable and larger, at up to almost USD 1000 per ha for the same tree spacing with different alley widths. The degree of competition among trees and grass seemed to be the most important variable in determining financial outcomes—and, unfortunately, the one that we know the least about. Complete Excel summaries of these analyses are available from the corresponding authors at their respective emails.

Table 4. Big Bluestem Alley-Cropped Competition Modeling Displaying Potential NPV Revenues (USD/ha) in Response to Tree Density and Competition over 25 years, using 4\% discount rate, USD, 2019.

\begin{tabular}{|c|c|c|c|}
\hline \multirow[b]{3}{*}{ Tree Spacing (m) } & \multicolumn{3}{|c|}{ Big Bluestem Alley-Cropped NPV Projections (USD/ha) } \\
\hline & \multicolumn{3}{|c|}{ NPV (12 m Alleyway) } \\
\hline & Pessimistic & Optimistic & No Interaction \\
\hline $3.0 \mathrm{~m} \times 3.0 \mathrm{~m}$ & USD 2050.25 & USD 2647.32 & USD 3269.88 \\
\hline $2.4 \mathrm{~m} \times 3.0 \mathrm{~m}$ & USD 1941.25 & USD 2637.59 & USD 3666.42 \\
\hline $2.4 \mathrm{~m} \times 2.4 \mathrm{~m}$ & USD 1930.33 & USD 2626.67 & USD 3655.50 \\
\hline \multirow[t]{2}{*}{$1.8 \mathrm{~m} \times 3.0 \mathrm{~m}$} & USD 1518.04 & USD 2201.91 & USD 3739.38 \\
\hline & \multicolumn{3}{|c|}{ NPV (24 m alleyway) } \\
\hline Tree Spacing (m) & Pessimistic & Optimistic & No Interaction \\
\hline $3.0 \mathrm{~m} \times 3.0 \mathrm{~m}$ & USD 2205.46 & USD 3597.28 & USD 2812.05 \\
\hline $2.4 \mathrm{~m} \times 3.0 \mathrm{~m}$ & USD 2132.85 & USD 3452.32 & USD 3055.98 \\
\hline $2.4 \mathrm{~m} \times 2.4 \mathrm{~m}$ & USD 1946.85 & USD 3058.30 & USD 3318.89 \\
\hline \multirow[t]{2}{*}{$1.8 \mathrm{~m} \times 3.0 \mathrm{~m}$} & USD 1720.18 & USD 2799.35 & USD 3175.90 \\
\hline & \multicolumn{3}{|c|}{ NPV (36.5 $\mathrm{m}$ alleyway) } \\
\hline Tree Spacing (m) & Pessimistic & Optimistic & No Interaction \\
\hline $3.0 \mathrm{~m} \times 3.0 \mathrm{~m}$ & USD 1956.44 & USD 3111.01 & USD 2381.90 \\
\hline $2.4 \mathrm{~m} \times 3.0 \mathrm{~m}$ & USD 2020.58 & USD 3261.24 & USD 2712.95 \\
\hline $2.4 \mathrm{~m} \times 2.4 \mathrm{~m}$ & USD 2219.00 & USD 3487.12 & USD 2880.76 \\
\hline $1.8 \mathrm{~m} \times 3.0 \mathrm{~m}$ & USD 1698.52 & USD 2908.72 & USD 2853.52 \\
\hline
\end{tabular}

Note: 1 ha $=2.47$ ac.

\section{Discussion}

This research performed a bioeconomic analysis of a forage and timber silvopasture field trial at the Center for Environmental Farming Systems (CEFS) in the Coastal Plain of eastern North Carolina, U.S. This research builds on a prior trial elsewhere on CEFS and provides further analyses of the merits of agroforestry and silvopasture systems in the southern U.S.

After six growing seasons, average tree height was similar for all spacings, ranging from 7.3 to $8.2 \mathrm{~m}$ ( 24 to $27 \mathrm{ft}$.). Average diameter at breast height was the smallest for the $2.4 \times 2.4 \mathrm{~m}(8 \times 8 \mathrm{ft})$ spacing, at $14.7 \mathrm{~cm}(5.8$ inches $)$, and similar for the others ranging from $16.1 \mathrm{~cm}$ to $17 \mathrm{~cm}$ (6.5 to 6.7 inches) $\mathrm{dbh}$. The $2.4 \times 2.4 \mathrm{~m}$ timber monoculture had the largest average volume, at 8.2 tons per ac, (18.3 metric tons per ha), followed by $1.8 \times 3.0 \mathrm{~m}, 3.0 \times 3.0 \mathrm{~m}$, and $2.4 \times 3.0 \mathrm{~m}(6 \times 10,10 \times 10$ and $8 \times 10 \mathrm{ft})$ spacings Understory species diversity was higher in the planted tree bands than in forage alleys, but the species composition in both areas was not of high value for grazing or hay production.

Our ALLEY 2.0 forest stand simulations, calibrated to the six-year growth, and grass yields assuming competitive interaction with the trees showed that the trees on the experimental site had exceptional growth rates due to good soil and fertilizer conditions on this old field. As a result, timber monocultures generated the highest net present value per ac at a 4\% discount rate, ranging between USD 1334 per ac (USD 3335 per ha) and USD 1437 per ac (USD 3593 per ha) for this site. Timber returns also were greater than the monoculture pasture/hay with NPVs of USD 750 per ac (USD 1853 per ha) for big bluestem to USD 1045 per ac (USD 2581 per ha) for switchgrass. The blended returns of timber and switchgrass pasture were then intermediate, depending on the proportion of timber and pasture and the amount of competition assumed.

As noted, the alley cropping/silvopasture results indicate that the spacing of trees within the bands of trees led to modest differences in net present values given fixed 
alley widths and competition assumptions. The "pessimistic" assumption of intensive tree and grass competition did lead to consistently lowers NPVs than optimistic or no interaction assumptions, as one would expect. The degree of competition among trees and grass seemed to the most important variable in determining financial outcomes-and, unfortunately, the one that we know the least about. The effect of alley width was more variable in the optimistic and no interaction assumptions, almost requiring a case-by-case analysis and inspection to determine the best outcome.

We also should note that our results depend on many inputs and assumptions in the ALLEY 2.0 Program, including loblolly pine timber growth and yield, grass growth by year, and competition effects. While each of these three model factors were based on the best available biological production functions and available scientific literature, each of these surely have considerable variation and uncertainty by themselves, which would increase with the interactions in the overall model. Thus, our results and their interpretation need to recognize this uncertainty, and they seem reasonable but certainly are not absolute.

The higher returns of timber relative to pasture at a low $4 \%$ discount rate matched the findings by Bruck et al. [8] on the other CEFS site. However, they found that including the production of beef livestock as a separate single product on open fields still had the highest present values per are of USD 3194 per ha. This indicates that managing beef throughout the entire value chain on open fields could be most profitable. However, additional research is needed to assess the returns associated with combining alley cropping of trees and pasture and the transition to livestock as the trees grow old enough for rotational grazing.

One intermediate mechanism that has been proposed, especially for dairy cattle, is the cut and carry system, where forage is cut from fields or alley cropping and carried in loose bundles on wagons to cattle in barns or small paddocks [36]. This has been considered at CEFS, but managers have decided not to do this with the possible pine needle-hay forage mixtures. However, cattle have grazed in southern pine stands for decades, so cut and carry should be feasible. It would need more evaluation, perhaps with hardwood trees as well, before it is implemented in the South.

Further research on how such integrated systems impact product market risk and environmental benefits is desirable, as well. Farming risk can be substantial. Traditional risk reduction through diversification might simply include a farm mosaic approach including two or more annual crops whose yearly price and yields are relatively uncorrelated [37]. Since alley cropping systems such as the one modeled here still have only one annual crop component, year-to-year risk may not be reduced significantly [38]. However, alley cropping can lower risk in other ways. Alley cropping systems tend to buffer against catastrophic crop losses, which may become more prevalent with climate change [39]. Inclusion of a timber component allows the producer to have flexibility in the length of the timber rotation, potentially choosing to harvest when timber prices are high [40] or to compensate for other losses or household needs. Finally, although we generally assumed somewhat competitive interactions between trees and forage in this research (though the optimistic scenario includes a short period of slight complementary effects while trees are young), other research has found that complementary interactions can boost agroforestry expected returns above those of traditional diversified farm mosaic with no increase in risk [40]. Such could be the case for silvopastures that boost livestock productivity by reducing heat stress [41].

Research on ecosystem services of agroforestry systems in temperate North America is somewhat scarce relative to other parts of the world. Relevant research that has been conducted suggests that silvopasture systems can sequester more carbon and capture excess nutrients relative to open pastures [42-47]. Future research can explore how these ecosystem services and others, including biodiversity, vary relative to various potential management regimes and how emerging markets for those services could impact returns and risks. However, the potential environmental benefits of agroforestry will be irrelevant if producers do not adopt the system. Key barriers to adoption of agroforestry are lack of familiarity with potential financial benefits and lack of knowledge about management 
prescriptions [4,48]. Our research provides a step toward filling those gaps by providing financial comparisons of agroforestry to conventional land management and by assessing the impact of tree spacings.

Animal welfare benefits research also is important. While not modeled here, livestock may fare well under light tree canopy covers, even with less grass, because they lose less body weight from heat and stress and spend more time grazing than resting, even if there is slightly less grass [29]. Dairy cattle in silvopasture systems may also produce as much or more milk, have better reproduction rates, and thus have more ability to be certified for good animal welfare practices or natural system dairy products [19].

The growth rates for loblolly pine produced by our ALLEY 2.0 model are at the upper end of typical ranges for North Carolina and much of the U.S. South. For instance, drawing from Cubbage et al. [49], updated with 2020 forest management costs, the returns for a medium intensity loblolly pine investment with growth of $10 \mathrm{~m}^{3} / \mathrm{ha} / \mathrm{yr}$ (4 tons/ac/yr) would only have an NPV of USD 687 per ha, or a LEV of USD 1100 per ha at the $4 \%$ discount rate (USD 275/ac and USD 440/ac), respectively. Loblolly pine often grows relatively fast on old-field sites, but the lower growth rates for typical forest lands reported in Cubbage et al. [49] indicate that the grass returns calculated here usually would be greater than returns from loblolly pine timber production. This suggests that some incentives might be necessary to attract landowners to use silvopasture systems.

For this second CEFS trial, timber monocultures had higher NPV/LEV returns at $4 \%$ discount rate, whereas pasture monocultures had higher IRRs. Silvopasture had NPVs and LEVs that were intermediate between the two. NPV/LEV maximization is the optimal strategy for an entity with access to capital at a fixed interest rate (the discount rate) but relatively constrained amount of land. IRR maximization is the optimal strategy for an entity with relatively limited capital but availability of land [35]. It should also be noted that the $1.8 \times 3.0 \mathrm{~m}(6 \times 10 \mathrm{ft})$ tree spacing and big bluestem forage treatment saw negative financial returns at then $4 \%$ discount rate over the 25 -year rotation age, indicating that higher tree densities can be detrimental to forage returns.

Our findings are congruent with those reported in Bruck et al. [8] whereby timber monoculture returns were greater than pasture returns, indicating that silvopasture blends can be attractive for farms. However, southern average timber financial NPV returns [27] would be about equal to or less than pasture returns. As such, converting pastures to silvopasture may not be a financially attractive option in many areas of the South. Thus, financial incentives such as Farm Bill conservation programs or compensation for the broader ecosystem services in silvopasture systems may be necessary to attract landowners to silvopasture.

The alley cropping and silvopasture returns in general will depend on the comparative returns for each component of the system, the blend of the two or more components, and competition or complementarity between the joint products. We examined three degrees of competition from intense to none but did not explore the possibility that forage grass and trees could be complements and produce more of both products without reducing the output of either. We do hypothesize that there could be small levels of trees, such as $5 \%$ to $25 \%$ of the area of the silvopasture system, where complementarity could exist. This possibility should be examined in future research.

Our results imply that silvopasture might be a viable alternative to monoculture pine plantation, pasture, or row-cropping systems for entities for which land and capital are both limited to a similar degree. Such could be the case for small-scale, limited-resource landowners who have a relatively small parcel of land and relatively little access to personal financing or loans.

\section{Conclusions}

Based on empirical measurements, literature review, managers' opinions, and computer modeling, the biological and financial tradeoffs of an intercropped loblolly pine and warm-season grass system in North Carolina were determined. For this field trial 
site, timber was the most profitable investment in terms of net present value for 25 years period, ranging from USD 3196.18 to USD 3551.86 per ha (USD 1294 to USD 1438 per ac). The modeled high productivity of timber is likely influenced by decades of fertilizer and corresponding agricultural management activities. Discounted switchgrass alley-cropped treatments usually were less profitable, with NPVs ranging from USD 2173.60 to USD 3826.03 per ha (USD 880 to USD 1549 per ac) depending on the tree spacing and degree of competition. The $2.4 \times 3.0 \mathrm{~m}(8 \times 10 \mathrm{ft})$ tree spacing for switchgrass alley crop had the best returns of the silvopasture treatments for an optimistic tree-grass interaction scenario with $24 \mathrm{~m}$ alleys. Using the ALLEY 2.0 model, the assumptions about the degree of competition between trees and grasses was the most important factor affecting NPVs. Either alley spacing or tree spacing was second or third most important in determining financial returns, but which one varied depending on the competition effects assumption.

Based on subsequent sensitivity analyses, alley cropping could become an optimal management choice when timber prices drop between $20 \%$ to $25 \%$ or if forage prices increase $10 \%$ to $15 \%$ of our original price assumptions. We also noted that higher discount rates-or internal rate of return as a capital budgeting criterion-would favor grasses, which have much sooner annual returns than waiting for timber harvests.

Many more long-term silvopasture experiments will be necessary to properly analyze a diversity of silvopasture systems that include the complex integration of trees, crops, grasses, and livestock and integrated production functions and competition effects. Nonetheless, this silvopasture trial has contributed to the growing body of evidence that alley cropping with forage and trees can serve as a financially competitive management option for landowners. It can also help landowners diversify their income sources and reduce single product market risks, as well as provide many ecosystem benefits discussed in the literature. Last, it certainly suggests that individual land management analyses, management decisions, and varied practices will be needed, since we could not make universal generalizations about what factor determined financial returns the most. There is a wealth of needs and opportunities for research, extension, land management, and professional advice to be developed to implement these alley cropping and silvopasture practices in the future.

Author Contributions: Conceptualization, K.D., L.U.S., J.I., and F.C.; Data curation, L.U.S., G.F., and F.C.; Formal analysis, K.D., L.U.S., J.M., and G.F.; Funding acquisition, J.I., D.S., and F.C.; Investigation, K.D., L.U.S., J.M., G.F., J.I., and F.C.; Methodology, K.D., L.U.S., J.M., G.F., J.I., D.S., and F.C.; Project administration, L.U.S., D.S., and F.C.; Resources, L.U.S., D.S., and F.C.; Software, J.M. and G.F.; Supervision, L.U.S., J.M., G.F., and F.C.; Writing—original draft, K.D., L.U.S., and F.C.; Writing-review and editing, F.C., K.D., G.F., D.S., J.M., and J.I. All authors have read and agreed to the published version of the manuscript.

Funding: This research received no external funding. It was supported by the contributed time of each individual co-author as employees of their respective institutions and NC State University operating equipment and vehicle expenses to travel to the field site.

Institutional Review Board Statement: Not applicable.

Informed Consent Statement: Not applicable.

Data Availability Statement: As noted, above, a summary working copy of the spreadsheet with all the analyses for the project are available from the corresponding authors.

Acknowledgments: The authors acknowledge and thank the Research Stations Division of the North Carolina Department of Agriculture and Consumer Services the permission to use the land for the field trials, for their equipment and staff for the experimental site establishment and maintenance, and for access to historical land use records for the site.

Conflicts of Interest: The authors declare no conflict of interest. The findings and conclusions in this publication are those of the authors and should not be construed to represent any official State of North Carolina or USDA or U.S. Government determination or policy. 


\section{References}

1. United Nations. Sustainable Development Goals. Available online: https://www.un.org/sustainabledevelopment/ (accessed on 20 September 2021).

2. Husak, A.L.; Grado, S.C. Monetary benefits in a southern silvopastoral system. S. J. Appl. For. 2002, 26, 159-164. [CrossRef]

3. Frey, G.E.; Fike, J.H.; Downing, A.K.; Comer, M.M.; Mize, T.A.; Teutsch, C.D. Trees and livestock together: Silvopasture research and application for Virginia farms. In Proceedings of the Seventh National Small Farm Conference, Virginia Beach, VA, USA, 20-22 September 2016; Volume 2017, pp. 1-7.

4. Workman, S.W.; Bannister, M.E.; Nair, P.K.R. Agroforestry potential in the southeastern United States: Perceptions of landowners and extension professionals. Agrofor. Syst. 2003, 59, 73-83. [CrossRef]

5. Grado, S.C.; Hovermale, C.H.; St Louis, D.G. A financial analysis of a silvopasture system in southern Mississippi. Agrofor. Syst. 2001, 53, 313-322. [CrossRef]

6. Shrestha, R.K.; Alavalapati, J.R.R.; Kalmbacher, R.S. Exploring the potential for silvopasture adoption in south-central Florida: An application of SWOT-AHP method. Agric. Syst. 2004, 81, 185-199. [CrossRef]

7. Sharrow, S.H.; Brauer, D.; Clason, T.R. Silvopastoral practices In North American Agroforestry: An Integrated Science and Practice, 2nd ed.; Garett, H.E., Ed.; American Society of Agronomy: Madison, WI, USA, 2009.

8. Jose, S.; Dollinger, J. Silvopasture: A sustainable livestock production system. Agrofor. Syst. 2019, 93, 1-9. [CrossRef]

9. Chatterjee, N.; Nair, P.R.; Chakraborty, S.; Nair, V.D. Changes in soil carbon stocks across the Forest-Agroforest-Agriculture/Pasture continuum in various agroecological regions: A meta-analysis. Agric. Ecosyst. Environ. 2018, 266, 55-67. [CrossRef]

10. Torralba, M.; Fagerholm, N.; Burgess, P.J.; Moreno, G.; Plieninger, T. Do European agroforestry systems enhance biodiversity and ecosystem services? A meta-analysis. Agric. Ecosyst. Environ. 2016, 230, 150-161. [CrossRef]

11. Bruck, S.R.; Bishaw, B.; Cushing, T.L.; Cubbage, F.W. Modeling the financial potential of silvopasture agroforestry in eastern North Carolina and northeastern Oregon. J. For. 2019, 117, 13-20.

12. Clason, T.R. Economic implications of silvipastures on southern pine plantations. Agrofor. Syst. 1995, 29, 227-238. [CrossRef]

13. Dangerfield, C.W.; Harwell, R.L. An analysis of a silvopastoral system for the marginal land in the southeast United States. Agrofor. Syst. 1990, 10, 187-197. [CrossRef]

14. Frey, G.F.; Mercer, D.E.; Cubbage, F.W.; Abt, R.C. Economic potential of agroforestry and forestry in the lower Mississippi alluvial valley with incentive programs and carbon payments. S. J. Appl. For. 2010, 34, 176-185. [CrossRef]

15. Lundgren, G.K.; Conner, J.R.; Pearson, H.A. An economic analysis of forest grazing on four timber management situations. South. J. Appl. For. 1983, 7, 119-124. [CrossRef]

16. Stainback, G.A.; Alavalapati, J.R.R. Restoring longleaf pine through silvopasture practices: An economic analysis. For. Policy Econ. 2004, 6, 371-378. [CrossRef]

17. Alavalapati, J.R.R.; Shrestha, R.K.; Stainback, G.A.; Matta, J.R. Agroforestry Development: An Environmental Economic Perspective. In New Vistas in Agroforestry; Springer: Dordrecht, Holland, 2004; pp. 299-310.

18. Zinkhan, F.C.; Mercer, D.E. An assessment of agroforestry systems in the southern USA. Agrofor. Syst. 1996, 35, 303-321. [CrossRef]

19. ASPCA. Creating a More Humane World for Farm Animals. Available online: https://www.aspca.org/shopwithyourheart/ consumer-resources / meat-eggs-and-dairy-label-guide\#Certifications (accessed on 20 September 2021).

20. Hartsell, A.J. Forest Statistics for Mississippi Counties-1994; Research Paper 190; Southern Forest Experiment Station: New Orleans, LA, USA, 1995.

21. Cumbie, W.P.; Isik, F.; McKeand, S.E. Genetic improvement of sawtimber potential in loblolly pine. For. Sci. 2012, 58, 168-177. [CrossRef]

22. Anderson, E.W.; Scherzinger, R.J. Improving quality of winter forage for elk by cattle grazing. Rangel. Ecol. Manag. /J. Range Manag. Arch. 1975, 28, 120-125. [CrossRef]

23. Keyser, P.D.; Harper, C.A.; Bates, G.E.; Waller, J.; Doxon, E. Native Warm-Season Grasses for Mid-South Forage Production. Available online: https:/ / extension.tennessee.edu/publications/Documents/SP731-A.pdf (accessed on 1 October 2021).

24. Barker, D.J.; MacAdam, J.W.; Butler, T.J.; Sulc, R.M. Forage and Biomass Planting. Available online: https:/ / www.nrcs.usda.gov / Internet/FSE_DOCUMENTS/stelprdb1080494.pdf (accessed on 1 October 2021).

25. Cubbage, F.; Glenn, V.; Myers, R.; Robison, D.; Mueller, P.; Luginbuhl, J.; Myers, R. Early tree growth, crop yields, and estimated returns for an agroforestry trial in Goldsboro, North Carolina. Agrofor. Syst. 2012, 86, 323-334. [CrossRef]

26. USDA Forest Service. Forest Vegetation Simulator (FVS). Available online: https://www.fs.fed.us/fvs/ (accessed on 22 August 2021).

27. Virginia Tech Forest Modeling Cooperative. PTAEDA. Available online: https://fmrc.frec.vt.edu/Models/ptaeda4.html (accessed on 22 August 2021).

28. Frey, G.E.; Cary, M.A.; Goodwin, B.K.; Mercer, D.E. Agroforestry Land-use Economic Yield and Risk (ALLEY) Model 2.0: A Computer Suite to Simulate and Compare Stochastic Yield and Returns of Alley Crop, Monocrop, and Pine Plantation Systems in the US South. Available online: https:/ / www.fs.usda.gov/treesearch/pubs/57480 (accessed on 1 October 2021). 
29. Pent, G.J.; Fike, J.H. Winter Stockpiled Forages, Honeylocust Pods, and Lamb Performance in Hardwood Silvopastures \& Sheep Performance and Behavior in Silvopasture Systems. In Proceedings of the Agroforestry for a Vibrant Future: Connecting People, Creating Livelihoods, Sustaining Places., 15th NAAC on the Campus of Virginia Tech in Blacksburg, Blacksburg, VA, USA, 27-29 June 2017; pp. 27-29. Available online: https: / /www.aftaweb.org/images/documents/15th-NAAC-Easy-to-navigateConference-Abstract-Proceedings.pdf (accessed on 1 October 2021).

30. Pent, G.J. Over-yielding in temperate silvopastures: A meta-analysis. Agrofor. Syst. 2020, 94, 1741-1758. [CrossRef]

31. Maggard, A.; Barlow, R. Costs and Trends of Southern Forestry Practices. Available online: https://www.aces.edu/blog/topics/ forestry/ costs-trends-of-southern-forestry-practices-2018/?cn-reloaded=1 (accessed on 1 October 2021).

32. Agricultural and Resource Economics. Forage Budgets Agricultural and Resource Economics NC State University. Available online: https:/ / cals.ncsu.edu/are-extension/business-planning-and-operations/enterprise-budgets/forage-budgets (accessed on 27 August 2020).

33. Forest2Market. Southern Timber Prices Continued to Slide in 3Q2019. Available online: https://www.forest2market.com/blog/ southern-timber-prices-continued-to-slide-in-3q2019 (accessed on 27 August 2020).

34. Hay Reports. USDA Federal Hay Reports Agricultural Marketing Service. Available online: https://www.ams.usda.gov/marketnews / hay-reports (accessed on 27 August 2020).

35. Mercer, D.E.; Frey, G.E.; Cubbage, F.W. Economics of Agroforestry. Available online: https:/ /www.taylorfrancis.com/books / edit/10.4324/9780203105290/handbook-forest-resource-economics-shashi-kant-janaki-alavalapati (accessed on 1 October 2021).

36. AHDB Dairy. Cut and Carry: A Best Practice Guide; AHDB Dairy: Warwickshire, UK, 2021; 32p. Available online: https: // projectblue.blob.core.windows.net/media/Default/Dairy/Publications/CutCarryA4_1777_190204_WEB.pdf (accessed on 13 September 2021).

37. Paut, R.; Sabatier, R.; Tchamitchian, M. Modelling crop diversification and association effects in agricultural systems. Agric. Ecosyst. Environ. 2020, 288, 106711. [CrossRef]

38. Frey, G.E.; Cary, M.A. Under what management and policy scenarios can alley cropping be a competitive alternative in the United States Southeast? Agrofor. Syst. 2020, 94, 2167-2183. [CrossRef]

39. Cary, M.A.; Frey, G.E. Alley cropping as an alternative under changing climate and risk scenarios: A Monte-Carlo simulation approach. Agric. Syst. 2020, 185, 102938. [CrossRef]

40. Frey, G.E.; Mercer, D.E.; Cubbage, F.W.; Abt, R.C. A real options model to assess the role of flexibility in forestry and agroforestry adoption and disadoption in the Lower Mississippi Alluvial Valley. Agric. Econ. 2013, 44, 73-91. [CrossRef]

41. Paul, C.; Weber, M.; Knoke, T. Agroforestry versus farm mosaic systems-Comparing land-use efficiency, economic returns and risks under climate change effects. Sci. Total Environ. 2017, 587, 22-35. [CrossRef]

42. Nair, V.D.; Nair, P.K.R.; Kalmbacher, R.S.; Ezenwa, I.V. Reducing nutrient loss from farms through silvopastoral practices in coarse-textured soils of Florida, USA. Ecol. Eng. 2007, 29, 192-199. [CrossRef]

43. Nair, V.D.; Haile, S.G.; Michel, G.A.; Nair, P.K. Environmental quality improvement of agricultural lands through silvopasture in southeastern United States. Sci. Agric. 2007, 64, 513-519. [CrossRef]

44. Udawatta, R.P.; Jose, S. Carbon sequestration potential of agroforestry practices in temperate North America. In Carbon Sequestration Potential of Agroforestry Systems; Springer: Dordrecht, Holland, 2011; pp. 17-42. Available online: https://www. springer.com/gp/book/9789400716292 (accessed on 1 October 2021).

45. Dold, C.; Thomas, A.L.; Ashworth, A.J.; Philipp, D.; Brauer, D.K.; Sauer, T.J. Carbon sequestration and nitrogen uptake in a temperate silvopasture system. Nutr. Cycl. Agroecosyst. 2019, 114, 85-98. [CrossRef]

46. Baah-Acheamfour, M.; Carlyle, C.N.; Bork, E.W.; Chang, S.X. Trees increase soil carbon and its stability in three agroforestry systems in central Alberta, Canada. For. Ecol. Manag. 2014, 328, 131-139. [CrossRef]

47. Nyakatawa, E.Z.; Mays, D.A.; Naka, K.; Bukenya, J.O. Carbon, nitrogen, and phosphorus dynamics in a loblolly pine-goat silvopasture system in the Southeast USA. Agrofor. Syst. 2012, 86, 129-140. [CrossRef]

48. Stutzman, E.; Barlow, R.J.; Morse, W.; Monks, D.; Teeter, L. Natural resource professionals' engagement with landowners on silvopasture in the Southeastern United States. Agrofor. Syst. 2020, 94, 2137-2146. [CrossRef]

49. Frederick, C.; Kanieski, B.; Rubilar, R.; Bussoni, A.; Morales, V.; Balmelli, G.; MacDonagh, P.; Lord, R.; Hernández, C.; Zhang, P.; et al. Global timber plantation investments, 2005-2017. For. Policy Econ. 2020, 112, 102082. 